\title{
Planning and Allocation of Digital Learning Objects with Augmented Reality to Higher Education Students According to the VARK Model
}

\author{
Antonia Mireles Medina*, Francisco Javier Carrillo García, José Angel Montes Olguín \\ Instituto Tecnológico Superior Zacatecas Norte (México)
}

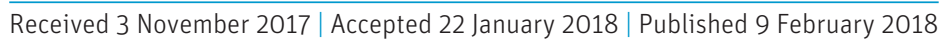

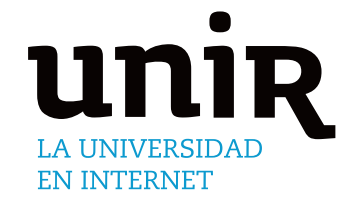

\section{ABSTRACT}

KEYWORDS

In the present research, the authors propose the planning, assignment and use of digital learning objects with augmented reality according to the learning style of students in higher education, according to the VARK Model. It is found that students with treatment have had better results in their final grades than students who have not undergone the treatment of having used digital learning objects with augmented reality. The digital objects of learning (DLO's) with augmented reality designed according to the learning style of the students are an attractive and adequate option so that the teachers who are the main responsible for the didactic planning can spread the knowledge in the students. So that traditional forms of education are put aside and as a result of taking advantage of Information and Communication Technologies that have come to break with the paradigms that have prevailed for years in the teaching - learning process. On the other hand, education based on e-learning platforms facilitates the training of students at a distance allowing them to build and self-manage learning, as well as facilitate the dissemination of digital learning objects with augmented reality according to the learning style according to the VARK Model.
Learning Digital Objects, VARK Model, Teachinglearning Process, Augmented Reality, E-learning.

\section{INTRODUCTION}

DUCATION and the teaching-learning process evolved throughout Chistory to allow the development of different models, techniques and tools that the teacher uses to transmit knowledge to their students. Students can acquire the necessary skills to function in the workplace, however, there are some factors that influence for a student fails a course, these factors may be related to: a) The student. Diversity in learning styles, IQ (Intelligenz-Quotient), interpersonal relationships, ability to work as a team, b) The teacher. Teaching style, didactic strategy, c) The external context. Family, social and economic situations, space physical conditions, among others. The present research studies the need to consider the student learning style as a factor to pass a subject.

In the teaching-learning process the student learning style must agree with the teacher's teaching style, on this topic the Instituto Tecnológico Superior Zacatecas Norte has a particular interest for improving their teaching methods and techniques.

In this study participated 18 students, the course is "Taller de Investigación II", they are in the seventh semester, this course belongs to the 2009-2010 study plan on the "Ingeniería en Administration" career. This course supports the student's certification process of the "Tecnológico Nacional de México", and allows the writing, presentation and defense of the research project [1].

To assign digital learning objects with augmented reality to support

* Corresponding author.

E-mail address: mirelesmed_7@hotmail.com the teaching-learning process at the higher education students taking into account the student learning style, according to the VARK Model, is the general objective for this research. [2] mention, "The teacher is no longer the main information source, but rather a person who promotes the learning of cognitive and metacognitive strategies so that the student can convert for himself all that information that he receives in knowledge and knows how to apply it to different areas and situations ". They also comment that "work with digital learning objects facilitates and favors attention to diversity." Digital learning objects (DLO) have to be commensurate with their learning style, DLO's are designed based on the needs of each student.

DLO's according to [3] are characterized by presenting a series of audiovisual, interactive and dynamic activities that favor the development of student skills such as visualizing, guessing, analyzing, among others, these objects are designed based on the needs of each student. DLO's are small pedagogical elements that allow a great flexibility of access through the web [4]; they can also be accessed through local networks, desktop computers, mobile devices such as Tablet, Smartphone, among others.

The reason for proposing the use of DLO's is because an object of learning is a unit that has a meaning by itself and as such can be integrated into different contents or contexts of teaching and learning so sustain it [2]. The authors of this research agree with the authors that the objects of learning have value in themselves and can be used in the educational field with all freedom of time by the student, ie not necessarily in the classroom if not in your study space. Another reason is that learning objects as they say [5] may consider "interoperability that refers to the ability of two or more systems to exchange information, 
and then reuse that information" advantage that the present authors article emphasize, because ODAS can be reused as needed or the opportunity presented, this means that they can be overexploited in the sense that they can not only be used once.

For the purposes of this article, based on the learning styles proposed by the VARK model, it is a simple and appropriate instrument to identify teaching - learning styles; this instrument was developed by Neil Fleming in conjunction with Collen Mills in 1992 according to [6]. The model is called VARK (Visual, Aural, Read / Write, Kinesthetic) of the sensory modalities that they identified as Visual, Auditive, Reading and Kinesthetic or Kinesthetic, as it affirms [7]. Similarly, they say that people select information according to their interests or preferences to learn. According to González, [8], "each individual can present from one to the four modalities with all their combinations". However, in order to identify such modalities, the corresponding questionnaire must be applied to the following website: http://vark-learn.com/elcuestionario-vark/. The questionnaire consists of 16 multiple choice questions, with four possible answers, which should only select one.

According to [6], the instrument for the identification of the learning style initially consisted of 13 questions with three and four possible answers, however for the year 2006 it was modified as already described in the previous paragraph. Below are described each of the sensorial modal preferences considered in the VARK model according to the [9]:

a) Visual (visual): preference for graphical and symbolic ways of representing the information.

b) Reading / writing: preference for printed information in the form of words

c) Auditive (aural): preference for listening the information.

d) Kinesthetic: perceptual preference related to the use of experience and practice, whether real or simulated.

It is crucial and vital that teachers at higher level institutions know the learning styles of their students, so that they can provide them with the right tools and thus achieve the acquisition of learning in a simple way. This is stated by [10]: "In educational processes it is important to take into account the characteristics associated with how students can learn, that is, their predominant learning style, their skills and participate in meaningful learning". Identifying learning styles in the student should become a daily task in those who are dedicated to facilitating knowledge. [11] refer to 38 instruments to identify learning styles. For the purposes of this research, the VARK model is used.

The teaching-learning process is considered as "the movement of the cognitive activity of the students under the direction of the teacher, towards the mastery of the knowledge, the skills, the habits and the formation of a scientific conception of the world" [12]. In this respect there is the constructivist theory, where Piaget, Ausubel and Vygotsky stand out; the first makes two contributions from the epistemological theory: knowledge as construction of schemes and levels of cognitive development. On the other hand, the contributions of the second author deal with significant learning and previous knowledge. Vygotsky is awarded as a key contribution to school education as a development context, the area of proximal development and the teacher as mediator, according to Betoret Teaching Strategies for Learning Styles [13]. This research rescues significant learning, previous knowledge and the teacher as mediator of knowledge.

Another concept to highlight in this article is augmented reality, which combines the real and virtual world so that it includes synthetic information to perceived real world images. Augmented reality must be interactive, real-time and 3D alignment, since virtual world information must be three-dimensional [14]. The same authors argue that augmented reality has its applications in medicine, manufacturing, entertainment and advertising, nevertheless it can be applied in the educational field. In the case of this research, it is also important to resume e-learning, which can reach a large number of students, can tailor e-learning activities tailored to individuals, and can provide help by instructors among colleagues [15].

\section{Methodology}

\section{A. Description of the Context and Objects of Study}

The research was carried out in a group of 18 students of seventh semester of Engineering in Administration of the "Instituto Tecnológico superior Zacatecas Norte" that study the subject "Taller de Investigación II", taking into account the topic, "desarrollo de la metodología del proyecto de investigación". Such topic contains the following subtopics: "2.1 Aplicación de los instrumentos y métodos experimentales seleccionados"; "2.2 Desarrollo de la metodología"; "2.3 Recolección y tratamiento de datos"; "2.4 Análisis de resultados"; "2.5 Propuesta de ajustes de parámetros de la investigación y/o del prototipo" [1].

\section{B. Itinerary of the Actions Carried Out}

The following is how the investigation of the use of digital learning objects with augmented reality according to the learning style of the students has been carried out.

1. Students have been asked to respond to the VARK questionnaire to identify their learning style.

2. At random, two subgroups of nine students were formed, each named group A and group B.

3. Following the sub-topics, a diagnostic test was developed that was applied to both groups to identify prior knowledge.

4. The two groups were given classes considering the sub-topics already mentioned. Group A has also been provided digital learning objects with augmented reality from each of the subtopics (it is specified that they have made use of them by means of Tablet and Smartphone according to their learning style). Group B was provided with DLO's with augmented reality, in addition, the teacher of the subject has not taken into account their style of learning for the delivery of sub-topics.

5. Students have been asked to answer a final questionnaire and perform exercises to identify if they actually acquired knowledge and improved on the basis of the diagnostic questionnaire.

6. Results were tabulated in the diagnostic test, exercises and final questionnaire, to identify if there was an improvement in their learning process when using LDO's with augmented reality.

\section{Student Learning Styles}

Fig. 1 shows the results of the learning styles of the seventh semester group. Fig. 2 shows the learning style of students who used LDO's.

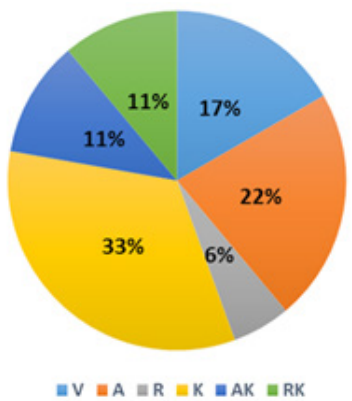

Fig. 1. Percentage of learning styles of the 18 students. 


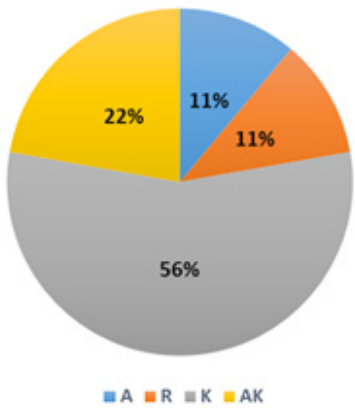

Fig. 2. Percentage of student learning styles that used LDO's.

As can be seen in Fig. 1, 33\% (6 students) are kinesthetic (K), while $22 \%$ (4) are auditory (A). The $17 \%$ (3) are visual (V). According to [8], these students are "unimodal". It can also be seen that $11 \%$ of students who are bimodal (AK) and (RK) coincide, that is, they stand out with two learning styles.

In Fig. 2, it can be seen that $56 \%$ have a kinesthetic learning style (K). The $22 \%$ is bimodal, since they have the preference to learn auditory (A)-kynesthetic (K). Finally, they coincide in an $11 \%$ reader / writer (R) and auditory (A). These students have been provided with LDO's with augmented reality. In Fig. 3, it can be seen that $34 \%$ have a visual learning style (V). $33 \%$ are auditory, $22 \%$ are reader (R) - kynesthetic $(\mathrm{K})$, that is, the latter corresponds to a bimodal learning style.

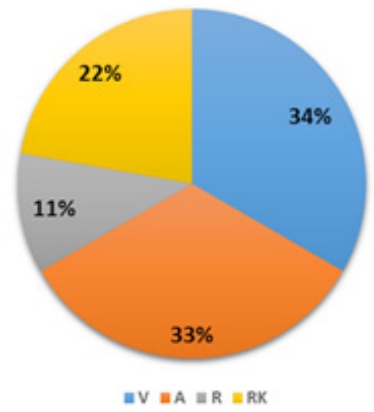

Fig. 3. Percentage of learning styles of students who did not use LDO's.

It is necessary to consider the recommendations of [16], which are shown in Table I. Based on these recommendations, students were assigned LDO's with augmented reality. These learning objects have consisted of videos, audio, booklets in digital and printed on each of the subtopics.

TABLE I. Teaching Strategies [16]

\begin{tabular}{|c|c|c|c|}
\hline \multicolumn{4}{|c|}{ Teaching Strategies for VARK Learning Styles } \\
\hline $\begin{array}{l}\text { Teaching } \\
\text { strategies for } \\
\text { visual style } \\
\text { Use of: } \\
\text { - Written } \\
\text { Instructions } \\
\text { - Conceptual } \\
\text { maps } \\
\text { - Diagrams, } \\
\text { models, } \\
\text { synoptic tables } \\
\text { - Computer } \\
\text { animations } \\
\text { - Videos, } \\
\text { transparencies, } \\
\text { photographs } \\
\text { and } \\
\text { illustrations. }\end{array}$ & $\begin{array}{l}\text { Teaching strategies } \\
\text { for auditory style } \\
\text { Use of: } \\
\text { - Verbal } \\
\text { Instructions } \\
\text { - Repeat similar } \\
\text { sounds } \\
\text { - Audio } \\
\text { - Debates, } \\
\text { discussions and } \\
\text { confrontations } \\
\text { - Brainstorming } \\
\text { - Read the } \\
\text { same text } \\
\text { with different } \\
\text { reflection } \\
\text { - Guided and } \\
\text { commented } \\
\text { reading. }\end{array}$ & $\begin{array}{l}\text { Teaching } \\
\text { strategies for } \\
\text { reader/writer } \\
\text { style } \\
\text { Use of: } \\
\text { - Write a } \\
\text { minute } \\
\text { - Literary } \\
\text { compositions, } \\
\text { journals, } \\
\text { blogs and } \\
\text { reports, } \\
\text { - Elaboration } \\
\text { summaries, } \\
\text { reviews and } \\
\text { synthesis of } \\
\text { texts, } \\
\text { - Review of } \\
\text { neer texts }\end{array}$ & $\begin{array}{l}\text { Teaching strategies } \\
\text { for kynesthetic } \\
\text { style } \\
\text { Use of: } \\
\text { - Role-play and } \\
\text { dramatization } \\
\text { - Group dynamics } \\
\text { that require } \\
\text { sitting and } \\
\text { standing } \\
\text { - The chalkboard } \\
\text { to solve problems } \\
\text { - Manipulation of } \\
\text { objects to explain } \\
\text { phenomena } \\
\text { - Gestures to } \\
\text { accompany oral } \\
\text { instructions. }\end{array}$ \\
\hline
\end{tabular}

\section{Evaluation Results}

The results of the evaluation are shown below. It is important to mention that the following criteria have been considered in the final grade of each student (CF): Written exam, product or practices, tasks, performance and attitude; these criteria are those proposed by the Instituto Tecnológico Superior Zacatecas Norte, on a scale of 0 to 100. The diagnostic test (DI) has been applied to students to identify prior knowledge. This test has been applied to both students who used DLO's and did not use it.

TABLE II. Student Results Who Have Used LDO's (Group A)

\begin{tabular}{ccc}
\hline $\mathrm{n}$ & $\mathrm{DI}$ & $\mathrm{CF}$ \\
\hline Student 1 & 60 & 100 \\
Student 2 & 60 & 100 \\
Student 3 & 80 & 100 \\
Student 4 & 80 & 100 \\
Student 5 & 30 & 90 \\
Student 6 & 60 & 100 \\
Student 7 & 20 & 80 \\
Student 8 & 50 & 90 \\
Student 9 & 40 & 100 \\
\hline
\end{tabular}

TABLE III. Student Results Who Have Not Used LDO's (Group B)

\begin{tabular}{ccc}
\hline $\mathrm{N}$ & $\mathrm{DI}$ & $\mathrm{CF}$ \\
\hline Student 11 & 30 & 100 \\
Student 12 & 20 & 90 \\
Student 13 & 100 & 100 \\
Student 14 & 70 & 100 \\
Student 15 & 50 & 85 \\
Student 16 & 50 & 85 \\
Student 17 & 10 & 57.5 \\
Student 17 & 60 & 58.5 \\
Student 18 & 50 & 80 \\
\hline
\end{tabular}

Obtained the results of Tables II and III have been replaced in the corresponding equations by means of a logical operation to make the comparison between the students who used LDO's and those who did not use LDO's and in this way to check if their academic performance has been improved with the use of LDO's.

\section{DATA ANALYSIS}

Once the data corresponding to the diagnostic examination (previous knowledge), exercises and final exam or questionnaire were tabulated, a comparison of the results between Group A and Group B was made to determine if there was actually an improvement in their learning process. For this the equation (1) has been designed:

$$
\mathrm{S}_{\mathrm{ODAS}}=\frac{\sum_{i=0}^{n} C F_{i}}{n}-\frac{\sum_{i=0}^{n} D I_{i}}{n}
$$

Where

$\mathrm{S}_{\mathrm{ODAS}}$ refers to students who used LDO's (Group A) and

$C F$ is the final grade of each student

$D I$ is the diagnostic test grade

$n$ is the total number of students

$$
\begin{gathered}
S_{O D A S}=\frac{860}{9}-\frac{480}{9} \\
S_{O D A S}=42.22
\end{gathered}
$$


Likewise, for students who have been given the class without LDO's (Group B) we have:

$$
\mathrm{S}_{\text {Sin_ODAS }}=\frac{\sum_{i=0}^{n} C F_{i}}{N}-\frac{\sum_{i=0}^{n} D I_{i}}{N}
$$

Where $\mathrm{S}_{\text {sin_ODAS }}$ refers to students who did not use LDO's and

$C F$ is Final grade of each student

$D I$ is Diagnostic test grade

$\mathbf{N}$ is Total number of students

$$
\begin{gathered}
S_{\text {Sin_ODAS }}=\frac{756}{9}-\frac{440}{9} \\
S_{\text {Sin_ODAS }}=35.11
\end{gathered}
$$

In order to determine if the use of LDO's effectively supports and improves the academic performance of the student, the following logical operation is considered: $\mathrm{S}_{\text {ODAS }}>\mathrm{S}_{\text {sin_ODAS }} \mathrm{S}$ where: $42.22>35.11$, it is higher, therefore, students who made use of the LDO's have a better performance or academic achievement.

\section{HyPOTHESIS TESTING}

Likewise, for a better accuracy in the obtained results a hypothesis test is applied that is shown in Table IV.

TABLE IV. HyPothesIS TESTING

\begin{tabular}{ccc}
\hline & 100 & 100 \\
\hline Arithmetic average & 95 & 82 \\
Variance & 57.1428571 & 269.5 \\
Observations & 8 & 8 \\
Pearson correlation coefficient & 0.80006709 & \\
Hypothetical difference of means & 0 & \\
Degrees of freedom & 7 & \\
Statistic $\mathrm{t}$ & 3.24909357 & \\
$\mathrm{P}(\mathrm{T}<=\mathrm{t})$ a tail & 0.00703746 & \\
Critical value of $\mathrm{t}(\mathrm{a}$ tail) & 1.89457861 & \\
$\mathrm{P}(\mathrm{T}<=\mathrm{t})$ two tails & 0.01407491 & \\
Critical value of $\mathrm{t}$ (two tails) & 2.36462425 & \\
\hline
\end{tabular}

The hypotheses are proposed, the null hypothesis against the alternative hypothesis: $H_{0}: U_{1}=U_{2}$ e $H_{1}: U_{1}>U_{2}$

Thus, $\mathrm{t}_{\mathrm{c}}=3.25$ is in the rejection zone of $\mathrm{H}_{0}$, so it is accepted $\mathrm{H}_{1}$, as shown in Fig. 4.

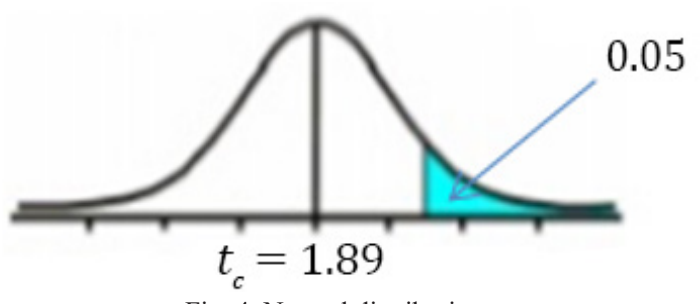

Fig. 4. Normal distribution curve.

\section{Summary of Results}

In this research work has been achieved the allocation and use of digital learning objects with augmented reality, to support the teachinglearning process of seventh-semester students of the "Ingeniería en Administration" career who have taken the subject of "Taller de Investigación II", considering the learning style of the student according to the VARK Model.
The authors recommend that the teacher be a mediator in the teaching-learning process and that their way of teaching is adapted to the student's way of learning, since this way the educational task can be facilitated.

Likewise, they propose the use of LDO's in the different educational levels and in the different subjects, since these can be adapted according to the nature of each topic or theme. Likewise, they recommend that LDO's be assigned to students in all topics of each subject.

Finally, it is important to mention that it is recommended to assign LDO's according to the learning style according to the VARK Model. Because the VARK model has a structure for collecting data faster, this is due to the number of queries it contains. Without a doubt, the use of LDO's makes the learning process more attractive and dynamic for students.

\section{CONCLUSION}

In conclusion, the group with treatment that corresponds to Group A has better results in its final scores than Group B that did not undergo any treatment. The hypothesis of $\mathrm{H}_{-} 0$, is rejected, whereas the hypothesis of H_1, is accepted, therefore, the use of LDO's with augmented reality supports and as a consequence improves the learning process of students. The objective of the research has been achieved. Likewise, it is considered essential that teachers know the learning style of their students, so that they look for the way to provide them with the necessary tools in their daily tasks in the classroom.

Taking advantage of new technologies in education is a task that should not be overlooked in the educational field, since technologies are useful tools to support the teaching-learning process. The use of digital learning objects with augmented reality is a feasible option that can be taken up so that not only in institutions of higher level are implemented, but in all educational levels.

Planning and assigning digital learning objects is a task properly focused on the teacher who teaches the subjects, this depends on success for the student to achieve an acceptable academic performance, that is, sufficient for the acquisition of passing grades, skills and competencies.

The didactic planning, the assignment and the use of digital learning objects imply the organization of a set of ideas and activities that allow to develop an educational process with meaning, meaning and continuity [17], the authors of this article consider it of the utmost importance that in the process - teaching and learning the teacher as the main responsible for the didactic planning provides students with digital objects with augmented reality to achieve sufficient academic performance. On the other hand, digital learning objects with augmented reality have reusability as a characteristic [18], this allows them to be used whenever the student requires it and in the same way they can facilitate their learning process and that the LDO's are assigned according to their learning style.

Finally, as stated by [19] the educational technology, gives high importance to the teaching work in its planning phase, so that based on the objectives, the contents are broken down, the learning activities and teaching resources are designed. They will lead to the expected behavior change and the evaluation is defined to corroborate the learning; the teacher must not forget his objective as facilitator of knowledge, so he must always keep in mind that a correct planning will lead him to achieve a better educational quality.

\section{ACKNOWLEDGMENT}

The authors of this article thank the "Instituto Tecnologico superior Zacatecas Norte" for the unconditional support to carry out this research. 


\section{REFERENCES}

[1] Tecnológico Nacional de México, «Asignatura Taller de investigación II, Clave ACA-0910, » México, 2016.

[2] I. C. Gordillo y I. Fernández Antelo, «Diseño y gestión educativa de objetos digitales de aprendizaje,» eUniverSALearning'08, 26-28 November 2008.

[3] W. d. Santos y P. Vedovatti, «El aula más allá de las paredes. Introducción a la tecnopedagogía mediante la integración de objetos digitales de aprendizaje, » 2015.

[4] M. C. López, R. Mora García, L. Rodríguez Valenzuela, E. Toledo Marhuenda, A. Jimenez Delgado y M. R. Pacheco Mateo, «Investigación en la mejora docente mediante Learning Objects,» pp. 3096-3111, January 2012.

[5] L. C. García, G. López Morteo, R. Morales Gamboa, J. Muñoz Arteaga, J. P. Contreras Paredes, J. J. Contreras Castillo, C. M. Curlango Rosas y R. Villa Angulo, «Diagnóstico de la capacidad para interoperar,» Norma Mexicana para la Interoperabilidad entre Entornos de Objetos de Aprendizaje, vol. 2, 2014.

[6] J. R. G. Nájera, «El modelo VARK: Instrumento diseñado para identificar estilos de enseñanza-aprendizaje,» INED, pp. 86-90, 2007.

[7] F. d. J. N. Cardenas, R. Hernández Palacios, V. T. Tomás Mariano y F. R. Felipe Redondo, «Identificación de Estilos de Aprendizaje en Alumnos Universitarios de Computación de la Huasteca Hidalguense mediante Técnicas de Minería de Datos, » Huejutla de Reyes, Hidalgo.

[8] B. González, C. Alonso y R. Rangel, «El modelo VARK y el diseño de cursos en línea,» Revista mexicana de bachillerato a distancia, pp. 96-103, 2011.

[9] M. Pedraza, «Los estilos de aprendizaje VARK UIS-Seminario de Orientación».

[10] E. L. O. Cañón, A. L. Sánchez Aradilla y A. Lozano Rodríguez, «REA y estilos de aprendizaje según Vark en el aprendizaje de matemáticas,» Revista Internacional Magisterio: Educación y Pedagogía, 64, pp. 91-93, 2013.

[11] J. L. G. Cué, J. A. Santizo Rincón y C. M. Alonso García, «Instrumentos de medición de estilos de aprendizaje,» Revista Estilos de Aprendizaje, pp. 2-23, 2009.

[12] K. H. Ortiz, Plataforma para el control del uso de software educativos, Cuba, 2009.

[13] F. D. Betoret, «La enseñanza y el aprendizaje situation educativa,» Aprendizaje y Desarrollo de la personalidad (SAP001), 2012.

[14] C. G. Morcillo, D. Vallejo Fernández, J. A. Albusac Jiménez y J. J. Castro Sánchez, Realidad Aumentada, Un Enfoque Práctico con ARToolKit y Blender, España: Bubok Publishing S.L., 2012.

[15] J. C. Almenara, «Bases pedagógicas del e-learning,» Revista de Universidad y Sociedad del Conocimiento (RUSC), Vol. 3, n 1, April 2006.

[16] Lozano, 2001. [On line]. Available: http://www.cca.org.mx/profesores/ cursos/cep21/modulo_2/modelo_vark.htm. [Last access: 03 Noviembre 2016].

[17] C. A. Peralta, «Adecuación de la Planeación Didáctica como Herramienta Docente en un Modelo Universitario Orientado al Aprendizaje,» Revista Iberoamericana sobre Calidad, Eficacia y Cambio en Educación, vol. 14, $\mathrm{n}^{\circ}$ 3, pp. 109-130, 2016.

[18] L. Zorita, A. López Medina, M. Latorre, M. Blázquez, E. San Cristobal, S. Martín, G. Díaz y M. Castro, «Creación de objetos digitales de aprendizaje y su inclusión en el repositorio institucional espacio -UNED,» AIESAD, vol. 17, $\mathrm{n}^{\circ} 1$, pp. 149-177, 2014.

[19] A. Tejeda y M. E, «La planeación didáctica, » 2009. [On line]. Available: http://webcache.googleusercontent.com/ search?q=cache:0ybCpUp1yrcJ:uiap.dgenp.unam.mx/apoyo_pedagogico/ proforni/antologias/LA\%2520PLANEACION\%2520DIDACTICA. $\mathrm{pdf}+\& \mathrm{~cd}=1 \& \mathrm{hl}=\mathrm{es} \& \mathrm{ct}=\mathrm{clnk} \& \mathrm{gl}=\mathrm{mx}$. [Last access: 19 December 2017].

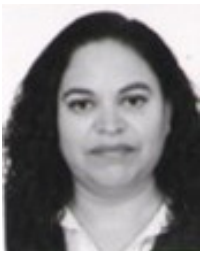

\section{Antonia Mireles Medina}

She was born in "Río Grande, Zac. México", on March 15, 1977. She is of Mexican Nationality.She graduated in 2000 with a degree in Informatics with a specialization in Information Systems at the "Instituto Tecnológico Superior Zacatecas Norte". She completed her studies corresponding to the Masters in Administration at the "Universidad Autónoma de Zacatecas". She has successfully completed her Bachelor of Laws studies in the "Universidad Autónoma de Durango, Zacatecas Campus". She has been teaching at the "Instituto Tecnológico Superior Zacatecas Norte" for 15 years. "Areas of interest are: Informatics, artificial intelligence, robotics, education and law.

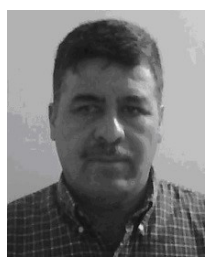

\section{Francisco Javier Carrillo García}

He was born in "Río Grande, Zacatecas, México", on September 10, 1957. He is 59 years old. Gender Male, Mexican Nationality. He graduated as a Mechanical and Electrical Engineer at the Autonomous University of Mexico, where he worked as a Professor for 12 years. Since September 1994 he works as a Professor at "Instituto Tecnológico Superior Zacatecas Norte". In September 2013, he obtained a Master's Degree in Science in Educational Mathematics from the "Universidad Autónoma de Zacatecas". His areas of interest are Mathematics and Electromechanical Engineering and Mechatronics.

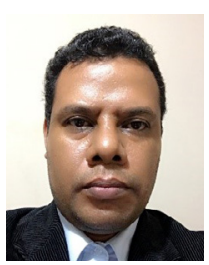

\section{José Angel Montes Olguín}

He was born in "Rio Grande, Zacatecas, México", on November 19, 1977. Mexican nationality. He graduated as a Bachelor in Computer Science at the "Instituto Tecnológico Superior Zacatecas Norte", where he worked as a Professor since 2005. His areas of interest are: Artificial Intelligence, Augmented Reality and Data Science, applied mainly to the areas of education and disability. 